University of Chicago Law School

Chicago Unbound

Journal Articles

Faculty Scholarship

2003

\title{
Terrorism and Insurance Markets: A Role for the Government as Insurer?
}

Alan O. Sykes

Follow this and additional works at: https://chicagounbound.uchicago.edu/journal_articles

Part of the Law Commons

\section{Recommended Citation}

Alan O. Sykes, "Terrorism and Insurance Markets: A Role for the Government as Insurer?," 36 Indiana Law Review 447 (2003).

This Article is brought to you for free and open access by the Faculty Scholarship at Chicago Unbound. It has been accepted for inclusion in Journal Articles by an authorized administrator of Chicago Unbound. For more information, please contact unbound@law.uchicago.edu. 


\title{
TERRORISM AND INSURANCE MARKETS: A ROLE FOR THE GOVERNMENT AS INSURER?
}

\author{
ANNE GRON* \\ ALAN O. SYKES**
}

\begin{abstract}
Since September 11, 2001, insurance markets have been struggling to adjust to new information about the magnitude of risks posed by terrorism, and to the loss of tens of billions of dollars in reserves because of claims relating to the September 11 attacks. Insurance coverage for terror-related losses has become more expensive and for some risks difficult or impossible to obtain. As a result, various interest groups called for the federal government to provide coverage for terrorism losses, resulting in the Terrorism Risk Insurance Act of 2002. We question the wisdom of measures of this sort. They are likely to come too late to address short-term market disruption, and in the long run may well supplant or distort desirable market responses to the new information about terrorism risk.
\end{abstract}

The terrorist attacks on the United States in September 2001 created chaos in the insurance industry. Insurers immediately refused to sell more than minimal coverage to any airline for ground damage, placing airlines in difficulty with both creditors and regulators. ${ }^{1}$ Property and casualty reinsurers, who will bear the brunt of the $\$ 40$ billion or more in claims resulting from the destruction of the World Trade Center, ${ }^{2}$ announced that they would no longer sell coverage for acts of terrorism. The insurance industry responded by announcing that acts of terrorism would be excluded from coverage under commercial policies in future renewals, a state of affairs that might place the owners of some commercial properties in breach of loan covenants and may leave commercial lenders hesitant to make new loans. ${ }^{3}$

The Bush administration quickly obtained temporary authority for the Federal Aviation Administration to provide insurance coverage to airlines for

* Assistant Professor of Management and Strategy, Northwestern University, Kellogg School of Business. B.A., 1984, magna cum laude, Williams College; Ph.D., Massachusetts Institute of Technology.

* Frank and Bernice Greenberg Professor of Law, University of Chicago Law School. B.A., 1976, College of William and Mary; J.D., 1982, Yale University Law School; Ph.D., 1987, Yale University.

1. See Barbara De Lollis, Airlines Plan to Create Insurance Company; Insurers Had Stopped Selling War Risk Policies After September $1 /$ Coverage, USA TODAY, Mar. 7, 2002, at 2B.

2. Jackie Spinner, Insurers See Terror Coverage Delays Unless U.S. Helps, WASH. POST, Jan. 18, 2002, at E3.

3. See Adrian Michaels, Insurance Chief Warns U.S. Business of Cover Loss: Terror Attacks Widespread Disruption and Breaches of Loan Covenants Predicted Unless Legislation Passed, FIN. TIMEs (London), Dec. 6, 2001, The Americas, at 12. 
ground damage, ${ }^{4}$ a program that remains in force subject to periodic votes on renewal. Broader proposals for government participation passed both houses of Congress and were signed by President Bush in November 2002. The legislation provided federal coverage for up to $90 \%$ of the cost of a terrorist attack that creates losses in excess of $\$ 10$ billion and up to a total of $\$ 100$ billion for three years. $^{5}$

This paper inquires whether a lack of insurance coverage for terrorist acts warrants government intervention, and in particular whether government should serve as the insurer of last resort going forward. Our answer to this question is a tentative "no." We stipulate at the outset that our general suspicion of government involvement rests more on empirical judgments, grounded in significant part on previous experiences with government as an insurer, than on tight theoretical arguments.

In brief, the problems with the affordability and availability of terrorism insurance can be divided into two categories. The first group of problems arises from the temporary capacity shortage attributable to the significant decline in industry capital following the events of September 11. These problems affect terrorism exposures of a low to moderately large magnitude which are diversifiable and thus would be insurable in a market not afflicted by a capacity shortage. Many of these temporary capacity shortages have occurred over the past several decades, with the most recent associated with catastrophe insurance in the early 1990s. These transitory periods of capacity shortage are often called insurance crises because they are characterized by large reductions in the availability of insurance (encompassing both increased deductibles and reduced limits) along with large price increases and, at times, a lack of coverage at any price for the lines most affected. The problems associated with the current capacity shortage are amplified because the events of September 11 occurred at a time when property-casualty insurance prices were already rising and insurers had significant risk overhang from other property policies in force. Those events caused insurers to revise upward their judgments about the probability of a terrorist act and the associated losses, but considerable uncertainty still exists about both. To manage this altered risk, insurers now want to rebalance their exposures geographically and better diversify their portfolios, a process which has made them reluctant to write new terrorism coverage.

The problems arising from a temporary capacity shortage and associated complications are short-term and can be expected to be self-correcting. For example, a little more than six months after the attacks, insurers were ready to begin writing some policies that they refused to sell six months earlier (such as substantial coverage for ground damage caused by airliners). ${ }^{6}$ Barring new shocks to the market, this trend should continue and availability and pricing for

4. See De Lollis, supra note 1.

5. Bush Signs Terror Insurance Bill Sought by Industry, SCRIPPS HOWARD NEWS SERV., Nov. 26, 2002.

6. Christopher Oster, AIG Urges FAA to End Airlines' War Insurance, WALL ST. J., Feb. $26,2002$. 
some terrorism coverage will likely improve substantially (although premiums will assuredly be higher, reflecting the higher expected loss). Any further government participation in the market for coverage of these losses is likely unnecessary and may well be counterproductive.

We note also that some of the adjustment will occur on the part of insureds, not just their insurers. If loan contracts call for borrowers to carry "all risk" insurance, for example, and coverage for one of the risks encompassed by that term (terrorism) is no longer available, borrowers and lenders have the option of adjusting their contractual relationship. Lenders can simply reprice the loans upward and waive the requirement of terrorism coverage. For many properties where the risk of terrorism is extremely low, the price adjustment will be trivial. And for types of properties where the risk is perceived to be great, it is hardly obvious that the lending market should proceed as if September 11 had never happened - it may well be desirable for some commercial development to be curtailed or reoriented in response to the greater threat of terrorism that now exists.

A second set of problems relates to insurance for large-scale, catastrophic terrorist acts, such as the detonation of nuclear weapons in major cities. To be sure, these types of events will likely remain uninsurable. But that has always been the case. Readers need do no more than glance at their homeowners' policies for evidence. They will likely find among the losses not insured such items as losses due to "acts of war," enumerated to include such acts as the discharge of a nuclear weapon. Similarly, losses due to nuclear hazard are likely excluded from coverage.? As we discuss further below, it is not difficult to understand why private insurers do not cover such losses. The essence of insurance is risk pooling and diversification, so that aggregate losses become predictable and insurers can have a high degree of confidence that their premiums and investment income will cover their loss payouts and expenses. Coverage for the rare but massive losses that threaten insurers with insolvency will only be offered (if at all) at a hefty premium above their actuarial value, a premium that insureds will likely find excessive in relation to their willingness to pay to lay off risk, and doubly so if insurer default is a concern.

If the private market lacks the capital to write coverage for these large and nondiversifiable losses, should the government step in to supply it? The short answer is that the government does supply it in a sense, although not through formal insurance contracts. Federal aid to New York City following the recent terrorist attacks was authorized at about $\$ 25$ billion. A compensation fund for victims has been established that will ensure each decedent's estate a six or seven figure payment. More generally, one would be hard-pressed to identify any large scale domestic catastrophe in modern times-whether flood, earthquake, volcanic eruption, or hurricane-where the federal government did not offer considerable aid after the fact.

The question then becomes a more subtle one-should the government enter

7. One of the authors' Illinois State Farm Homeowner's Policy contains all of these exclusions (on file with author). 
the insurance market ex ante and commit itself contractually to cover particular losses relating to terrorism, or should it instead rely on the private market to insure the diversifiable losses and step in with an appropriate aid package ex post in the event of something catastrophic and uninsured? We favor the latter approach, for three reasons. First, past experience with the government as formal participant in insurance markets is not comforting. The government rarely prices or manages risks as would a private insurer with sufficient capital, particularly when there is already a large constituency of policyholders and creditors advocating more coverage at lower prices. The result is a mix of subsidies, cross-subsidies, moral hazard and adverse selection that distort behavior, as well as improperly priced government insurance that may crowd out efficient private insurance. These distortions may well swamp any efficiencies from improved risk sharing. The "Terrorism Risk Insurance Act of 2002," passed by both houses of Congress in November 2002, is illustrative of the problem-the government will simply assume the losses incurred above a certain (rather low) aggregate, charging nothing for that protection and thereby subsidizing insurers who have already sold policies on the premise that they would have to cover at least some of those losses. ${ }^{8}$ Although this program is ostensibly "temporary," political pressures to leave this subsidy in place may prove irresistible. The beneficiaries are well-organized groups of insurers, real estate developers, and the like, while the losers are the diffusely organized and perhaps poorly-informed group of taxpayers at large.

Second, given past experience with government accumulation of funds for future disbursement, there is little reason to think that such funds would be treated much differently than general revenues. If insurance premiums would likely be based on political rather than economic considerations, and if accumulated premium revenues would be treated as fungible with other revenue sources, we see little reason to set up a new apparatus for the collection of insurance premiums.

Finally, in the event of the most catastrophic type of terrorist attack, governmental resources may be severely strained. It is by no means clear that ex ante arrangements committing scarce resources to particular property owners will allocate those resources most efficiently even with a $\$ 100$ billion cap on federal payments as enacted..

In offering these tentative judgments about the wisdom of government involvement, we are not unmindful of the evidence that a lack of terrorism coverage is presently causing genuine disruption in some markets. The press is replete with anecdotal references to project financing that is on hold because "all risk" coverage is unavailable. President Bush has cited the example of a large Nevada resort development that cannot obtain financing, and mortgage bankers and real estate developers seem widely supportive of government stepping into the breach.' But it simply does not follow that government should act. The real

8. Ins. Info. Inst, Hot Topics and Insurance Issues: Terrorism and Insurance, at http://www. iii.org/media/hottopics/insurance/sept 11\%.

9. Mark A. Hoffman, Bush Renews Push for Terror Cover Aid, Bus. INS., Apr. 15, 2002. 
estate industry and the lenders that support it would of course like to retum to the days before September 11 when terrorism risk was perceived to be a de minimis cost of doing business, and they will happily support programs to shift the increased risk to taxpayers. But terrorism risk is a cost like any other that ought to be internalized by developers, not externalized. If it cannot be laid off on insurers for the time being at a price that developers find congenial due to a capacity shortage, it does not follow that government should assume the risk instead. The optimal response to the short-term insurance crisis may well be for lenders and borrowers to revise their contracts to recognize that insurance is temporarily unavailable, and to reprice them accordingly. In the long term, any lasting policy exclusions for catastrophic losses due to terrorist acts should be no more disruptive to project finance than exclusions for acts of war, which have persisted without causing any great difficulty for decades.

The sections that follow develop and refine these arguments. We begin with some positive economics on the insurance industry and the "capacity constraints" that afflict it in times of uncertainty following large shocks, as well as some history relating to previous insurance "crises."

\section{THE ECONOMICS OF INSURANCE "CRISES"}

Crises in the availability of private insurance coverage are not unfamiliar. During the 1980s, certain lines of liability insurance increased in price spectacularly, and a few became altogether unavailable (such as certain lines of medical malpractice coverage). ${ }^{10}$ The most recent crisis occurred in the early 1990s following Hurricane Andrew when reinsurers exited the market for coverage of catastrophic risks, leading domestic casualty to insurers to fear that another major disaster might threaten their solvency." Such crises also produced political support for governmental actions to reduce insurers' exposure to risk, and indeed one can trace some modern tort reforms and initiatives such as the California Earthquake Authority in part to these episodes. ${ }^{12}$ The liability and catastrophe insurance crises also spawned a fair amount of theoretical and empirical research into the reasons for them.

\section{A. The Theory of Insurance Capacity Limits}

The insurance crises of the past, as well as the present situation with respect to terrorism coverage, all arose following large, unanticipated losses for insurers. At first blush, the unwillingness of insurers to sell coverage at such times, or a large increase in required premiums relative to expected losses, presents a puzzle. After all, insurers are in the business of bearing risk, and it is not obvious why an increase in the riskiness of their business would give them pause-premiums

10. See George L. Priest, The Current Insurance Crisis and Modern Tort Law, 96 YALE L.J. $1521,1521,1522,1527$ (1987).

11. See generally THE FinANCING OF CATASTROPHE RisK (Kenneth A. Froot ed., 1999).

12. Regarding the latter, see generally David A. Moss, Courting Disaster?: The Transformation of Federal Disaster Policy Since 1803, in id. at 307. 
will rise when the expected value of covered losses rises to be sure, but why should insurers refuse to write coverage at all or charge premiums far in excess of expected losses? Instead, one might expect insurance actuaries to take their best guess regarding future expected losses as new information comes in, and to make coverage available for a premium that covers expected costs.

Insurance crises are part of a larger pattern of pricing and availability in insurance markets, sometimes referred to as the insurance cycle. During the crisis phase, the most affected lines of business experience rapidly increasing prices accompanied by severely restricted quantity. Coverage may become unavailable for a very few types of losses and insureds. During this time most insurers realize great improvements in profitability and are able to increase their capital from retained earnings. Over time, the crisis phase or tight market lessens and prices may fall as the availability of coverage significantly increases. This period of relative stability typically gives way eventually to a soft market where prices are quite low, availability is abundant, and insurer profitability is quite low. The soft market generally persists until another large, unanticipated industry loss reduces industry capacity to the point where another crisis arises.

Various theories have emerged through the years to explain insurers' behavior during tight markets. Some economists argued that tightness was due to foolish loss forecasting that underpredicted losses during periods of rising losses and overpredicted them during periods where losses had stabilized, rather akin to the famous "cobweb" model of naive price forecasting in elementary microeconomic theory. ${ }^{13}$ The difficulty with this theory, of course, is that it relies on perpetual stupidity on the part of insurance actuaries, not a very appealing assumption. It also fails to explain why insurance coverage might become unavailable altogether.

Others have suggested that regulatory drag contributes to cycles, with periods of increased losses followed by periods during which regulators constrain the ability of insurers to write coverage in order to protect solvency. ${ }^{14}$ These theories primarily aim at explaining the time series pattern of profitability across the cycle and are not well suited to explain the quantity changes associated with profit movements over the cycle. The claim that regulation is the central reason for cycles is at best incomplete. Reinsurance markets are largely unregulated, for example, yet some of the most prominent "crises" (including the catastrophic risk situation in the early 1990s and the dearth of terrorism coverage) arose from an unwillingness of reinsurers to write coverage.

With particular reference to the 1980s' liability crisis, still other writers suggested that adverse selection in the commercial casualty market was the problem. As losses grew due to changes in liability rules, the story ran, the difference in risk exposure between "good types" and "bad types" increased, leading more "good types" to exit the insurance market leaving behind "bad

13. See generally Emilio C. Venezian, Ratemaking Methods and Profit Cycles in Property and Liability Insurance, 52 J. RISK \& INS. 477 (1985).

14. J.D. Cummins \& J.F. Outreville, An International Analysis of Underwriting Cycles in Property-Liability Insurance, 54 J. RISK \& INS. 246, 250 (June 1987). 
types" and higher premiums. ${ }^{15}$ This theory has some explanatory power, but has a more difficult time with crises in other lines of insurance such as the recent catastrophe insurance crisis in the early 1990s (where adverse selection seems much less of a problem), and it does not explain some elements of the 1980s' liability crisis. For example, many liability policies were canceled during the crisis, but adverse selection should not cause insureds or insurers to cancel insurance that is sold before the market begins to unravel. ${ }^{16}$ In addition, if the market was unraveling during the liability insurance crisis, why did total premiums collected approximately triple? ${ }^{17}$ An unraveling market should produce a drop in premiums. ${ }^{18}$

Another line of theory emphasizes capital market constraints on insurers as an explanation for tightness in the market. ${ }^{19}$ The key assumption is that external capital is more expensive than internal capital. For insurance companies in particular, it is likely that the capital markets will be suspicious of insurers trying to raise capital in the face of a recent increase in loss payouts. Some such insurers may simply be seeking the reserves needed to write profitable new policies, but others may be hoping to externalize the costs of expected future losses to unwitting new investors. If investors have difficulty telling these categories of insurers apart, all insurers may pay a hefty risk premium for outside capital, especially following a substantial increase in covered losses.

In general, when external capital is more expensive than internal capital, the value of any firm is likely to be concave in internal capital, causing the firm to act as if it is risk averse. ${ }^{20}$ This situation arises from the fact that some positive value investment projects will be profitable if financed using internal funds but not if financed using external funds. A reduction in available internal capital thus reduces the firm's willingness to undertake some new investment projects, while an increase in internal capital makes more projects profitable. Because investment opportunities exhibit diminishing returns, however, a reduction in internal capital is more costly than a comparable increase in internal capital, producing the concavity noted above. Significant bankruptcy costs can produce a similar result.

An insurer operating under these conditions will act as if it is risk averse and will manage its insurance portfolio to reduce the variance of the returns. ${ }^{21}$ As a

15. See Priest, supra note 10, at 1562; Ralph A. Winter, The Liability Insurance Market, 5 J. ECON. PERSP. 115, 123, 124, 131 (Summer 1991).

16. See Anne Gron \& Andrew Winton, Risk Overhang and Market Behavior, 74 J. Bus. 591, $606(2001)$.

17. See Winter, supra note 15 , at 126 (reporting that net premiums written rose from $\$ 6.5$ billion to $\$ 19$ billion during the $1984-86$ episode).

18. Id.

19. See Anne Gron, Capacity Constraints and Cycles in Property-Casualty Insurance Markets, 25 RAND J. ECON. 110, 112 (Spring 1994); Gron \& Winton, supra note 16.

20. Gron \& Winton, supra note 16 , at $594,607$.

21. The same argument applies to the typical corporation, offering an explanation of why otherwise risk neutral firms purchase insurance and engage in other forms of risk management. A 
result, the insurer will require a positive risk premium to assume risks that are positively correlated with other risks in the portfolio (a negative "risk premium" is also possible as to risks that are negatively correlated with the other risks in the portfolio). ${ }^{22}$ Insurers who effectively diversify their insurance portfolios will be able to offer lower prices (for a given probability of bankruptcy). Competition among insurers will thus lead insurers to manage their insurance portfolios to diversify risks either by directly adjusting their exposures sold or by the use of various types of reinsurance. ${ }^{23}$ As a result, the risk premia required by different insurers for the same type of risk will tend to converge.

With this background, it is easy to see how internal capital affects the "capacity" of the insurance industry. The capacity theory of cycles posits that insurance crises arise from a temporary shortage of industry capital. To go from the firm level discussion above to what happens at the industry level, note that because each insurer's ability to bear risk is related to its individual level of capital, the aggregate risk that the industry will assume at a reasonable probability of solvency is related to the aggregate level of capital that insurers have in the short run.

The level of capital in the industry is subject to random shocks arising from shocks to asset values and unexpected loss realizations. Unexpected losses can come from several sources but often arise when insurers have underestimated the probability or severity of large losses. Unusually large and unexpected declines in industry capital will result in a temporary capacity shortfall. After a large shock that changes the perceived probability distribution of losses, insurers will update their estimate of their existing exposure to risk associated with policies currently outstanding. Because of their limited capital and increased exposure to the risk in question, insurers will require a larger risk premium to bear additional risk of this sort.

Many insurers may want to cede this risk rather than assuming more. If reinsurance is available, insurers can rebalance existing exposures relatively quickly. ${ }^{24}$ But if the reinsurance industry is also experiencing a temporary capital shortage and an increased exposure to the risk, as is typically the case, insurers (and reinsurers) may rebalance their exposures to the risk by waiting until existing policies expire and not renewing, or, in the extreme, they may cancel existing policies when cancellation is contractually possible. ${ }^{25}$ This situation has been termed "risk overhang" in the literature. ${ }^{26}$

The problems from these capacity shortages tend to diminish over time for

full discussion of the motivations for corporate risk management are beyond the scope of this paper. For more on the portfolio approach to corporate risk management, see Kenneth A. Froot et al., Risk Management; Coordinating Corporate Investment and Financing, 48 J. FIN. 1629 (Dec. 1993).

22. For a formal model of such an insurance market, see Gron \& Winton, supra note 16, at 595, 596.

23. Priest, supra note 10, at 531.

24. Gron \& Winton, supra note 16 , at 606.

25. Priest, supra note 10, at 531.

26. Gron \& Winton, supra note 16. 
three reasons. First, the high prices due to the high return for scarce capital allow insurers (and reinsurers) to increase their internal capital. Second, those same high returns provide incentives for insurers to access costly external capital and for new entrants to come into the market. Third, insurers will reduce their risk exposure by curtailing new coverage and renewals as noted. The duration of the tight market conditions depends upon how quickly all three of these occur.

This theory of insurer behavior has some considerable empirical support. As the theory would predict, measures of insurers' "capacity" (internal capital) bear a significant relationship to insurers' profitability. ${ }^{27}$ Likewise, the theory predicts that the effects of "overhang" on current markets will last longer if previously issued policies have long-tailed coverage. ${ }^{28}$ For example, many liability policies cover "occurrences" during the policy period, even if liability judgments associated with them may not be forthcoming for many years because of delays in litigation or latent injuries. Under property insurance, by contrast, coverage is generally for "events" during the policy period, and there is little risk of a covered loss coming to light after the policy period is over. Accordingly, risk overhang will likely persist longer in liability insurance markets than in property insurance markets if the theory is correct. Recent evidence supports the theory, as the 1980s' liability insurance crisis lasted considerably longer than the early 1990 s' catastrophe reinsurance crisis. ${ }^{29}$

Before leaving this preliminary economic discussion, we wish to touch on one other point relating to large losses. As noted in the introduction, some types of losses, such as acts of war, are generally excluded from coverage under property-casualty policies. ${ }^{30}$ The preceding discussion adds to our understanding of why this should be so. Losses associated with war will tend to be highly correlated across policyholders. Consequently, they can seriously threaten insurers' internal capital. A healthy insurer will thus be unwilling to sell insurance for such risks without tacking on a substantial risk premium to the price. The more the price of insurance exceeds its expected value, other things being equal, the less the demand among potential insureds. This problem is compounded by the fact that large correlated losses may impair insurers' capital to the point that they will be unable to pay claims, a prospect that further reduces the demand for insurance.

Thus, certain types of losses will only be insurable by the largest insurers with the greatest capital reserves and the highest degree of global diversification. As the number of potential insurers diminishes, market power issues may become a concern. Some potential losses are so catastrophic and non-diversifiable that no insurer will insure them for a price that customers will pay.

27. See Gron, supra note 19.

28. Gron \& Winton, supra note 16, at 592 (explaining that "tail" means length of time that it takes for a claim to be entered against an old insurance policy).

29. See id. at 601,602 (reporting that the duration was roughly three years for the liability crisis as compared with one and a half years for the catastrophe reinsurance crisis).

30. Priest, supra note 10, at 1540-43 (discussing why losses from nuclear war are uninsurable). 


\section{B. Implications for Terrorism Insurance}

The events of September 11 and their aftermath changed the information available to insurers in three ways. First, they suggested that the probability of very large terrorism losses was significantly greater than previously thought, or, in other words, the expected value of future losses rose considerably. Second, and related, they greatly heightened the possibility that losses caused by terrorists might be so large as to be uninsurable. Present concerns about the use of weapons of mass destruction by terrorists suggest that terrorism losses might conceivably be as great as those that might be experienced in wartime. Third, they greatly increased the uncertainty in insurers' subjective probability distributions regarding terrorism losses. The insurance industry must now adjust to these new conditions.

The increase in both the mean and the variance of insurers' subjective distribution of terrorism losses creates a short-term "crisis" in the availability of terrorism coverage through the risk overhang phenomenon described above. Insurers in the short term have increased the estimates of their exposure to terrorism risk. Many insurers have found that they have more exposure relative to their capital than they would like and are seeking to shed such coverage until they can manage the risk better. For some insurers this may entail covering some terrorism losses but managing them differently by selecting a different mix of exposures, as by insisting on a broader geographic area for the same number of risks.

As with past insurance crises, the problem is likely to go away with time. Barring massive new terrorist attacks, insurers' capital will increase, the perceived uncertainty about the distribution of losses will diminish, and insurers' risk premia for covering terror-related losses will fall. Upward repricing of future coverage for terror-related losses will then afford insurers a substantial degree of confidence that the coverage will be profitable.

We may also expect insurers to take steps in the months ahead to protect themselves against excessive exposure in the event of the most catastrophic terrorist attacks. Exclusions will be rewritten for a number of particular occurrences. "Act of war" exclusions, for example, may be rewritten to incorporate more clearly the use of weapons of mass destruction by individuals as well as by enemy states. The exclusion of any losses caused by such weapons, especially nuclear weapons, may become more common, as may nuclear hazard exclusions. "Bomb damage" is another category of loss that may become subject to greater exclusions and limitations. Such coverage might be excluded from basic casualty policies and available only through separate riders such as those for earthquake and flood damage in many jurisdictions. Coverage through separate riders allows insurers to take on risks selectively to ensure adequate diversification and also allows coverage to be priced more proportionately to each insured's exposure to risk. Insurers will also protect themselves through dollar limits of liability as they always have in the past.

These adjustments are well underway. Indeed, insurers are again willing to sell large amounts of coverage to airlines for ground damage caused by aircraft 
and are thus urging the government to exit that market. Coverage for terror damage under property-casualty policies will likely return before long as well, subject to the sorts of changes noted above.

Insurance companies are not the only sources of "insurance" against terrorrelated losses. The catastrophe reinsurance crisis of the early 1990s spurred the growth of new financial instruments that allow risks to be allocated to the capital markets. Catastrophe futures and catastrophe bonds now allow any investor to contract to make or receive state contingent payments in the event of disasters. Payments, in the event of a catastrophic loss, are dependent on aggregate indices of insurance industry losses, thus eliminating any adverse selection or moral hazard that these contracts might otherwise produce. ${ }^{31}$

The adjustments that we describe for insurance markets are not yet complete, and we cannot know quite when the market will settle into a new equilibrium. One may therefore ask whether there is any role for government during the transition to a more stable situation. Further, the new equilibrium will likely entail some additional coverage exclusions, as well as limits on the dollar value of coverage, which make certain risks uninsurable that might previously have been covered. One can further ask whether government should step in to make coverage of these risks available. To these issues we now turn.

\section{THE UNEASY (WEAK?) CASE FOR GOVERNMENT INVOLVEMENT}

Consistent with our prior discussion, it is useful to divide the analysis between "transition" issues relating to the period of risk overhang and longerterm issues relating to risks that are uninsurable in the private market.

\section{A. Transition Issues}

The transition is ongoing to a market free of the current risk overhang, and its duration will depend on future experience with terrorism-related losses. Initially governments around the world stepped in to provide ground damage coverage for airlines on an ostensibly temporary basis. Since then, governments in the United States, Germany, and France have passed government-sponsored terrorism reinsurance programs.

With respect to airline coverage, at least part of the impetus for government participation is regulatory. Airlines are required to carry substantial coverage for ground damage (for which airlines are strictly liable under U.S. tort law), and policy cancellations after September 11 evidently placed airlines into a situation in which they could not comply with such regulations. As a result, airlines subject to these cancellations were unable to fly legally. ${ }^{32}$ Some adjustment of government policy was in order at that point, and government provision of

31. See Christopher Lewis \& Kevin Murdock, Alternative Means of Redistributing Catastrophic Risk in a National Risk Management System, in THE FINANCING OF CATASTROPHE RISK, supra note 11 , at 51.

32. See Terror in the Air: Governments Are Still Under Pressure to Insure Airline Risk Terror, THE ECONOMIST, Mar. 23, 2002. 
insurance on a temporary basis may have been a reasonable choice among the available options (regulatory waivers or changes in liability rules being the others).

Even so, government involvement in the sale of airline coverage illustrates one of the important potential problems with government participation in the insurance market. At least some private insurers are once again willing to supply coverage but the airline industry objects that it is too expensive. As a result, government programs supplying temporary coverage have been extended beyond their original expiration dates. This policy obviously raises the concern that governments are supplying subsidized coverage, and that political pressures will induce continued coverage. In that event, government becomes the problem rather than the solution, crowding out private insurance with subsidized public insurance and allowing airlines to externalize the risks they create.

More generally, one must ask whether there is some market failure that government can constructively address. One familiar source of market failure is market power. It is conceivable that risk overhang creates a window of time in which market power may arise and be exploited. As noted above, some risks are so large and non-diversifiable as to be uninsurable, and others are large enough that only the most highly capitalized insurers will cover them. We would not expect market power to afflict the market for coverage of the latter types of risks in the long run because of competitive entry by large insurers or insurance groups. However, in a market afflicted by risk overhang, only the very largest insurer(s) with experience writing a particular kind of coverage might offer it for a time. During that window, premiums might include not only a significant risk premium but a monopoly markup as well.

The airline situation again offers a possible illustration. The largest insurance group in the world by capitalization, American International Group, Inc. ("AIG"), is precisely the group that has recently announced its willingness to supply ground damage coverage to airlines in amounts comparable to those available before September $11 .{ }^{33}$ However, the airlines complained vociferously that this coverage is overpriced and have persuaded governments to remain in the market for now. We cannot rule out the possibility that AIG's premiums contain a monopoly markup. If so, government participation on a temporary basis might be justified in principle. But it is also impossible to rule out the earlier hypothesis that government coverage is a subsidy, and that the higher price of private coverage reflects sensible repricing in the face of increased risk.

The broader question of whether the government should go beyond assistance to airlines to supply other reinsurance coverage that the market will not supply turns on somewhat different issues. As noted, the capacity limitations that create risk overhang likely result from the relatively high cost of external capital to insurers, particularly after a series of events that produces large, unexpected losses. The high cost of external capital, in turn, is likely a product of asymmetric information between insurers and capital markets and a related

33. See A Nation Challenged: The Insurers; Sales Are Resumed for Coverage of Airlines for Terror Damage, N.Y. TIMES, Sept. 25, 2001, at C4. 
fear of adverse selection by insurers with large exposure under existing policies. A perceived shortage of coverage can also result from the high risk premiums that insurers will charge to write new coverage when the uncertainty about expected losses is great.

Can these circumstances be viewed as a "market failure" remediable by the government? The answer is somewhat complicated. There can be no question that conditions of asymmetric information reduce the efficiency of markets relative to a world of perfect, symmetric information. To call this a "market failure," however, is to indulge the nirvana fallacy. Governments are in no better position than the capital markets to judge the riskiness of placing capital at risk in insurance markets. Indeed, for reasons that we will elaborate in the next section, there is good reason to think that when the government acts as an insurer, its risk portfolio will be inferior to that of the private sector. Government reinsurance, therefore, would likely be more threatened with adverse selection than private reinsurance. We can think of no other policy instruments that government might constructively employ to ameliorate the problem of asymmetric information directly.

If an insurance market is suffering from unraveling due to adverse selection, however, government may improve matters by making insurance coverage mandatory. In theory, the same possibility seemingly exists for reinsurance markets. It is difficult to imagine how mandatory reinsurance would be constructed, and it is more difficult to imagine how government would determine when a dearth of reinsurance (or a period where its price seems high) could be addressed through any policy of mandatory reinsurance. Finally, when the adverse selection problem is only temporarily acute following a shock to the market, the danger arises that any government policies along these lines would be outmoded by the time they were implemented.

One might also argue for government participation because private reinsurers facing capacity constraints will charge substantial risk premiums to write coverage that may result in large losses. These risk premiums relate to the concavity of the profit function with respect to internal capital, which derives from the high cost of external capital (and perhaps bankruptcy costs), as previously noted. Arguably, government does not face these problems. In the event of a large, unanticipated call on the resources of the government as reinsurer, the government can still borrow in the capital markets at an attractive rate (at least the major Western governments). It need not pay the sort of premium that private insurers must pay to attract external capital, and it need not worry about costs of financial distress. Thus, the argument might run, in normal times when capacity constraints are not terribly important for private insurers, government should not act as an insurer because the private insurers' small risk premiums and their superior ability to manage and administer risk surely trumps any gains from shifting risk to the less risk averse government. However, after a large shock that creates risk overhang accompanied by large risk premiums to compensate private insurers for writing new coverage, the government has a substantial, albeit temporary, advantage in risk bearing, and should enter the market to exploit it.

The difficulty with this argument for government involvement is that 
practical considerations may undermine any gains from temporary government participation as an insurer or reinsurer. The risk overhang problem abates with time, and may well diminish greatly before government can act to install a sensible program. Once the government program is in place, it may long outlive its usefulness. Government is unlikely to set premiums in actuarially sound fashion, and political pressures for subsidies will be intense. Once subsidized insurance is in place, a constituency to retain it indefinitely will emerge, and a considerable risk arises that poorly managed, but inexpensive, government insurance will crowd out efficiently structured private insurance.

In sum, we think it unlikely that government has much of a constructive role to play as an insurer in addressing the problems associated with temporary insurance "crises," whether in terrorism coverage or in some other line. In offering this conclusion, we stipulate that some sort of response was appropriate to avoid a regulatory shutdown of the airlines after September 11, and that government provision of ground damage insurance on a temporary basis appears to have been a tolerable response initially. The months to come should reveal whether the government can resist airline industry pressure for long-term subsidization of this coverage. We fear that if the govemment leaps into the business of providing terrorism insurance because of the risk overhang in the market, it could create long-term costs that would outweigh any short-term gains. A mix of inertia and political pressures make it unlikely that the government will respond properly, and in an appropriately transitory fashion, to these market disruptions that history suggests will resolve on their own.

\section{B. Long Term Issues}

It remains to consider whether government has some role to play in the long term. Thus, imagine a time in the not too distant future when insurers have accumulated enough experience with terror-related losses to be willing to supply coverage for the risks that they believe to be modest and diversifiable. Premiums will be higher than before September 11, and terror coverage for some insureds may have to be purchased separately. But coverage will be available in substantial dollar limits at premiums that are not terribly in excess of actuaries' best estimates of expected losses. At the same time, however, new exclusions in standard policies will likely make coverage for certain catastrophic terrorist acts unavailable altogether, such as acts involving the use of weapons of mass destruction. Here, the unavailability of coverage is not a transitory result of risk overhang, but a lasting manifestation of the fact that some losses are so large and undiversifiable that private insurers will not agree to cover them.

Should government offer to insure these types of losses? One might begin with a simple "no" based on the observation that there are numerous uninsurable losses, and government does not generally step in to cover them. Governments do not generally offer act of war coverage, for example, and it is not terribly difficult to understand why. In the event of a large scale war, a government promise to pay for losses might not be credible. Even in the event of smaller scale conflicts where the government's ability to pay might not be in issue, the optimal use of limited government resources may not be to reimburse property 
owners for their losses. The needs of national defense and the provisions of emergency food, shelter and medical care, may well represent a higher priority.

This is not to suggest that government should do nothing in the event of a national catastrophe that presents a privately uninsurable risk. Quite the contrary, the government should and does assist those who have suffered losses. It simply does so on the basis of an ex post assessment of priorities rather than ex ante contracts with some subset of the population that has elected to purchase insurance. The federal assistance to New York and the compensation fund for victims of the September 11 attacks noted in the introduction are clear examples.

Ex post humanitarian assistance in lieu of ex ante insurance arrangements assuredly fails to achieve optimal risk allocation in any sense. However, government should have other considerations in its objective function besides optimal risk sharing, including distributional considerations that pure insurance markets will not address and the other sorts of expenditure priorities noted above. It would be exceedingly difficult to write an ex ante contract that accurately specified the act of war contingencies for which the government's promise to pay was credible and that the fulfillment of such a promise would not divert scarce resources from higher valued uses. This observation, we suggest, may well suffice to justify an "ex post" approach to government assistance in the event of attacks on the nation.

However, we are mindful of possible arguments to the contrary. One such argument is that properly priced government insurance arrangements might create valuable incentives. To the extent that certain types of activities or properties are at greater risk of harm from terrorist attacks, appropriately calibrated insurance premiums might discourage especially risky activities, discourage the construction of new properties that might represent easy targets, and encourage anti-terrorist precautions.

Such an argument must rest on the notion that ex post assistance provides a de facto "insurance," the price of which is not connected to each insureds' risk, which results in moral hazard. We do not doubt that ex post government assistance will create some degree of moral hazard at the margin. Indeed a number of writers have suggested that government disaster assistance creates moral hazard in other contexts, such as with crop failure and flood insurance. ${ }^{34}$ These writers typically argue that market insurers are better able to police adverse selection and moral hazard problems than government and urge that government withdraw from disaster insurance and ex post disaster relief activities whenever the government presence discourages the purchase of private insurance that is otherwise available or "crowds out" private insurers. ${ }^{35}$

We concur, and we certainly do not entertain the possibility that government should supplant private insurers or reinsurers in the provision of terrorism coverage. The question here is a slightly harder one-should government shift

34. See George Priest, The Government, the Market, and the Problem of Catastrophe Loss, 12 J. RISK \& UNCERTAINTY 219 (1996); see also Scott Harrington, Rethinking Disaster Policy, 23 REGULATION 40 (2000).

35. Id. 
from the provision of ex post assistance to ex ante insurance coverage with respect to the terror risks that are uninsurable in the private market over the long run? In particular, could such a shift be justified by the superior risk avoidance incentives that would result? The answer, we believe, is "no," for two reasons.

First, although ex post aid in the event of terror attacks creates some degree of moral hazard, the effect may be relatively modest because aid to terror victims is likely quite incomplete and uncertain. For example, the notion that the owners of the Sears Tower will eschew valuable precautions against terrorism on the grounds that they expect something approaching full compensation from the government in the event of its destruction seems uncompelling. It is also uncompelling that Sears Tower owners can avoid any market penalty for lax security because its tenants are secure in the knowledge that their decedents will receive compensation for their deaths. Here, the moral hazard problem is simply far less acute than it is when farmers who plant their crops near a river that regularly floods are routinely reimbursed for their losses.

Second, even if properly priced government insurance would create some valuable incentives, there is little reason to expect that government insurance would be properly priced. The critics of federal disaster policies have already shown convincingly that when the federal government becomes involved in the sale of insurance against disasters, it does little to classify risks or price policies in an actuarially sound fashion. To the contrary, policies are typically subsidized and lacking in experience-related pricing. Moreover, legislators cannot resist the urge to aid disaster victims who prove to be uninsured after the fact, so rational, potential insureds may decline to purchase insurance despite subsidized premiums. ${ }^{36}$ In light of this experience, is there any reason to think that government terrorism coverage would be priced in a way that generated useful precautions against terror? Indeed, the Terrorism Risk Insurance Act of 2002 provides for federal reinsurance free of charge.

A second possible argument for government sale of ex ante insurance in lieu of government ex post aid is that even if premiums would bear little relation to those that an insurance industry actuary would set, accumulated premiums could create a sizable fund that could be used to finance aid to victims. This argument, too, seems unconvincing. Special government funds are fungible with general revenues (remember the Social Security "lock box"?). There is little reason to think that any such fund to aid terror victims would be segregated for the purpose that it ostensibly serves. There is also little reason to think that a segregated fund is necessary in any event. If the government needs a special reserve fund to aid terror victims, why not one to finance wars or to cover expenditures during a severe recession? Further, if a fund is somehow needed, what is the advantage of accumulating reserves through insurance premiums rather than general taxation? We have already disposed of the notion that insurance premiums are likely to create valuable incentives, and we are not aware of any other potential advantage to them. The notion that it is more equitable for potential terror

36. See Harrington, supra note 34, at 44; Moss, supra note 12, at 343-44; Priest, supra note 34. 
victims to contribute disproportionately to the fund through insurance premiums offers a possible argument, but a weak one at best, especially given that such individuals and companies may well contribute disproportionately to tax revenues already.

Even if government should not enter into the provision of terrorism insurance, other policy changes might be constructive. It has long been recognized that the tax treatment of insurance reserves against catastrophic loss (income is taxed as it accumulates) forces premiums higher and reduces private coverage. Other writers have urged reconsideration of this policy. ${ }^{37}$ Similarly, we do not rule out the possibility that government might somehow aid in promoting (or not impeding) alternative private instruments for laying off terrorism risks in the capital markets, such as catastrophe bonds and futures. But for the reasons given here, long-term government entry into the market for privately uninsurable terrorism risks seems ill-advised.

\section{CONCLUSION}

For the reasons developed above, the case for more widespread government participation in the market for terrorism insurance seems a weak one. Insurers and insureds are already adjusting to the post-September 11 environment. We fear that government involvement will prove at best unnecessary and at worst a source of serious long-term distortions of the market place. 